\title{
OUTCOMES ON QUALITY OF LIFE, WEIGHT LOSS, AND COMORBIDITIES AFTER ROUX-EN-Y GASTRIC BYPASS
}

\author{
Roberto Coelho Netto da Cunha COSTA ${ }^{1}$, Nagamassa YAMAGUCHI ${ }^{1}$, \\ Marco Aurelio SANTO², Daniel RICCIOPPO² and Paulo Engler PINTO-JUNIOR ${ }^{1,2}$
}

\begin{abstract}
Context - Bariatric surgery has become the most effective method for producing weight loss in obese patients. The evaluation of improvement of comorbidities and changes in the quality of life are important outcome factors; however, it is necessary to investigate whether they persist over the long term. Methods - A cross-sectional study was conducted on 143 obese patients from our institution from February 2007 to February 2008. These patients were divided into five independent groups, one being a control group, plus four other groups with 1,2,3,4 or more years following surgical Roux-en-Y gastric bypass with a silicon ring banded. quality of life forms and anthropometric measurements were performed and its scores correlated with social factors, weight loss success, and status of obesity-related conditions. Results - For the group that was 1 year postoperative, a significant percentage of excess body weight loss (EBWL\%) of $81.7 \%$ was observed. The groups with 2, 3, 4 or more years of post-surgical follow-up showed a EBWL decline, but without significant difference. The main comorbidity percentages in all patients who had the surgery was as follows: $69.7 \%$ for hypertension; $88.2 \%$ for diabetes mellitus; and $27.5 \%$ for arthropathy. There was a significant decrease in the rate for diabetes resolution $(P=0.035)$ observed by evolutionary assessment of the comorbidity resolution. The results obtained by BAROS were good, very good, or excellent in more than $96 \%$ of patients in all evaluations that were performed. The use of the Moorehead-Ardelt Questionnaire (M/A) demonstrated improvement in the quality of life. Moreover, the quality of life, when evaluated through SF-36, also showed improvement in all related areas after 1 year; however, after 4 years, improvement remained elevated only in the areas of general state of health and functional capacity. Conclusions - The Roux-en-Y gastric bypass procedure was able to achieve EBWL of $81.7 \%$ after 1 year following surgery, remaining steady with little decline after this period. Important resolution of comorbidities, such as hypertension and diabetes, was also seen. Immediate surgical outcomes assessed by SF-36 and M/A in the area of quality of life were satisfactory, but the general state of health and functional capacity areas were sustained satisfactory at a later time only.
\end{abstract}

HEADINGS - Bariatric surgery. Gastric bypass. Outcome assessment. Quality of life.

\section{INTRODUCTION}

Obesity is a universal disease of epidemic proportions and is increasing in prevalence. It is one of the main public health problems of modern society due to associated comorbidities affecting quality of life (QoL) in a significant manner.

The high prevalence of obesity has become as problematic as malnutrition. In the United States, $30.5 \%$ of the adult population is obese and $4.7 \%$ suffer from morbid obesity ${ }^{(6)}$, while in Canada, its prevalence in the population is $14.9 \%$ for obesity and $2.9 \%$ for morbid obesity ${ }^{(3)}$. In Brazil, according to data from the Geography and Statistics Brazilian Institute (IBGE), in the last 30 years the number of overweight men doubled (from $18.6 \%$ to $41 \%$ ), and the number of obese men tripled (from $2.8 \%$ to $8.8 \%$ ). Among women there was an increase of $50 \%$ in relation to being either overweight or obese ${ }^{(8)}$.

The impact of morbid obesity in physical and psychological health is significant. Several studies have shown an association between obesity and the manifestation or aggravation of a variety of other health problems that include cardiovascular diseases, diabetes mellitus, sleep apnea, some types of cancer, depression, and loss of QoL ${ }^{(13)}$. Moreover, obese individuals have a death risk increase of $50 \%$ to $100 \%$, compared with normal weight individuals ${ }^{(13,14,15)}$. There are 400,000 deaths attributed to obesity annually in the United States, and it has been identified as

Declared conflict of interest of all authors: none

Research performed at: Departamento de Cirurgia do Hospital do Servidor Público Estadual de São Paulo - HSPESP, e na Disciplina de Cirurgia do Aparelho Digestivo, Departamento de Gastroenterologia, Faculdade de Medicina da Universidade de São Paulo.

Hospital do Servidor Público Estadual de São Paulo; ${ }^{2}$ Unidade de Cirurgia Bariátrica e Metabólica, Disciplina de Cirurgia do Aparelho Digestivo, Departamento de Gastroenterologia, Hospital das Clínicas da FMUSP, São Paulo, SP, Brasil.

Correspondence: Roberto da Cunha Costa. Rua das Verbenas, Lote 06, ed. José Gonçalves, ap. 1201- Bairro: Ponta d’Areia. CEP 65076-640. São Luiz, MA, Brasil. E-mail: rc5490@hotmail.com 
the second most common cause of death, after smoking, due to modifiable risk factors ${ }^{(6)}$.

Presently, bariatric surgery is indicated for patients with a body mass index (BMI) greater than 40 or a BMI between 35 and 40 with comorbidities associated with obesity ${ }^{(16)}$. In line with this indication, the Roux-en-Y gastric bypass (RYGBP) has been the most preferred form of bariatric surgery both in Brazil and elsewhere in the world ${ }^{(2,7,23)}$. There has been great interest in the outcomes of this procedure in relation to the evolution of weight loss, the resolution of comorbidities, and its impact on the QoL. In spite of extensive literature favoring bariatric procedures, several questions remain: Does the weight loss acquired through this surgery continue long term? What are the long-term impacts of associated comorbidities like diabetes, arterial hypertension, and arthropathy? Can the type of surgery used be individualized? Does the favorable QoL impression of these patients remain long term postoperative?

The aims of this study were to evaluate the long-term health outcomes as they relate to QoL, the evolution of weight loss, and the resolution of comorbidities over several RYGBP postoperative periods.

\section{METHODS}

A total of 143 patients undergone silicone ring RYGBP by laparotomy at Hospital do Servidor Público Estadual de São Paulo (HSPESP) from February 2007 to February 2008 were enrolled in the study. The research protocol was approved by the ethics committee of $\operatorname{HSPESP}\left(\mathrm{n}^{\circ} 014 / 07\right)$.

The patients were divided into five groups, G1-G5, each one constituting $30,26,30,27$, and 30 patients, respectively. The groups were identified as follows: G1 included patients awaiting surgery (Control); G2 was 1 year post surgery (12 to 15 months); G3 was 2 years post (21 to 26 months); G4 was 3 years post ( 33 to 39 months); and G5 had 4 years or more of post-surgical follow-up. For the postoperative outcome evaluations we used the Bariatric Analysis and Reporting
Outcome System (BAROS) ${ }^{(17)}$ and the Medical Outcomes Study 36-item Short-form Health Survey $\left(\mathrm{SF}-36^{\mathrm{TM}}\right)^{(4,26)}$ questionnaires.

The BAROS questionnaire uses a standardized scoring system to evaluate various outcomes of bariatric surgery such as weight loss, comorbidities, and QoL. The number of points for each area are then summed and classified as failure, fair, good, very good, or excellent outcomes ${ }^{(17)}$.

On the other hand, the SF- $36^{\mathrm{TM}}$ survey is used to evaluate the QoL as a generic instrument focusing on the negative aspects (disease or illness) and the positive aspects (welfare) of health. The SF- $36^{\mathrm{TM}}$ is a multi-item scale questionnaire that evaluates points of several clinical components such as functional capacity, physical activities, bodily pain, general state of health, vitality, social and emotional problems, and mental health, and compares these same components of the patients' current health with those obtained one year previous $^{(4,26)}$.

The Kruskal-Wallis test was applied for statistical analysis of the anthropometric data from the BAROS and the SF$36^{\mathrm{TM}}$ questionnaires. When applicable, the Behrens-Fisher test for comparing one group to another group was used. For analysis of resolution among groups of comorbidities, the Test for Trends in Proportions was applied. A level of 0.05 was considered significant among groups.

\section{RESULTS}

Table 1 presents the age, gender, and anthropometric data for the five groups. No significant difference was found between groups who underwent the RYGBP surgery related to preoperative BMI, current BMI, and percentage of excess body weight loss (EBWL\%). The age and initial BMI were smaller in Group 1 than in the other groups.

The results for weight loss and the impact of comorbidities were similar between groups, while significant differences were found in the QoL between G2 and G3, showing a decline between the first and second years. However after 3, 4, or

TABLE 1. Patients characteristics and anthropometric profile

\begin{tabular}{|c|c|c|c|c|c|c|}
\hline & $\begin{array}{l}\text { Group } 1 \\
\text { n (30) }\end{array}$ & $\begin{array}{c}\text { Group } 2 \\
\text { n (26) }\end{array}$ & $\begin{array}{l}\text { Group } 3 \\
\text { n (30) }\end{array}$ & $\begin{array}{c}\text { Group } 4 \\
\text { n (27) }\end{array}$ & $\begin{array}{l}\text { Group } 5 \\
\text { n (30) }\end{array}$ & $P$ \\
\hline Age & $39.6(10.3)$ & $45.0(11.3)$ & $46.7(9.7)$ & $48.3(10.2)$ & $45.7(7.1)$ & 0.016 \\
\hline Gender ( $\%$ female) & $86.7(34.6)$ & $92.3(27.2)$ & $96.7(18.3)$ & $85.2(36.2)$ & $90.0(30.5)$ & 0.605 \\
\hline BMI initial & $45.4(5.3)$ & $49.4(7.9)$ & $49.3(6.6)$ & $52.1(10.3)$ & $49.3(5.6)$ & $0.013^{*}$ \\
\hline BMI preoperative & & $45.7(5.8)$ & $45.1(5.8)$ & $46.8(6.8)$ & $47.7(5.2)$ & 0.189 \\
\hline BMI postoperative & & $29.4(5.6)$ & $30.4(5.3)$ & $30.0(4.9)$ & $31.6(4.3)$ & 0.228 \\
\hline EBWL \% & & $81.7(21.4)$ & $78.2(26.4)$ & $78.6(20.0)$ & $72.2(14.2)$ & 0.478 \\
\hline
\end{tabular}

Data are presented as mean \pm standard deviation

*Kruskal-Wallis test; BMI: Body Mass Index. EBWL\%: Percentage of Excess Body Weight Loss 
more years, the score for the postoperative QoL was similar to that of the control group (Table 2).

TABLE 2. Bariatric Analysis and Reporting Outcome System scores for patients weight, comorbidity and quality of life $(\mathrm{QoL})$-Moorehead-Ardelt questionnaire.

\begin{tabular}{lccccc}
\hline & Group 2 & Group 3 & Group 4 & Group 5 & $\boldsymbol{P}$ \\
\hline Weight & 2.58 & 2.43 & 2.48 & 2.37 & \multirow{2}{*}{0.651} \\
& $(0.50)$ & $(0.63)$ & $(0,64)$ & $(0,61)$ & \\
Comorbidity & 1.31 & 1.77 & 1.63 & 1.27 & 0.195 \\
\multirow{2}{*}{ QoL } & $(1.05)$ & $(1.04)$ & $(1,11)$ & $(1,01)$ & \\
& 2.44 & 2.12 & 2.27 & 2.05 & $0.042 *$ \\
Total & $(0.72)$ & $(0.63)$ & $(0,61)$ & $(0,78)$ & \\
& 5.99 & 5.98 & 6.02 & 5.30 & 0.074 \\
\hline
\end{tabular}

Data are presented as mean \pm standard deviation

*G2 vs G3 $P=0,037$. Behrens-Fisher test

An evaluation of these postoperative groups revealed that the major prevalent comorbidities were arterial hypertension, diabetes mellitus, and arthropathy, and these aspects reached a resolution rate of $69.7 \%, 88.2 \%$ and $27.5 \%$, respectively (Table 3 ). When these comorbidities were evaluated separately by group, there was a statistically significant long-term decrease in the rate of the diabetes resolution (Table 4).

Using qualitative outcomes obtained from the BAROS questionnaire, it was observed that an index of very good or excellent reached $90 \%$ or higher only in Group 2 . When the number of outcomes was increased, the percentage of patients with good, very good, or excellent result was above $96 \%$ in all groups (Table 5).
Evaluation through use of the SF-36 ${ }^{\mathrm{TM}}$ questionnaire revealed important improvements in QoL related to health (QLRH) in all domains of patients who underwent RYGBP in comparison to the control group. On the other hand, individualized evaluation of these aspects showed significant improvement in QoL for the first three years post-surgery. However, after four years (G5) the domains such as physical aspect, pain, vitality, social and emotional aspects, and mental health, were similar to those of the control group, except for general state of health and functional capacity, which remained better (Figures 1A and 1B).

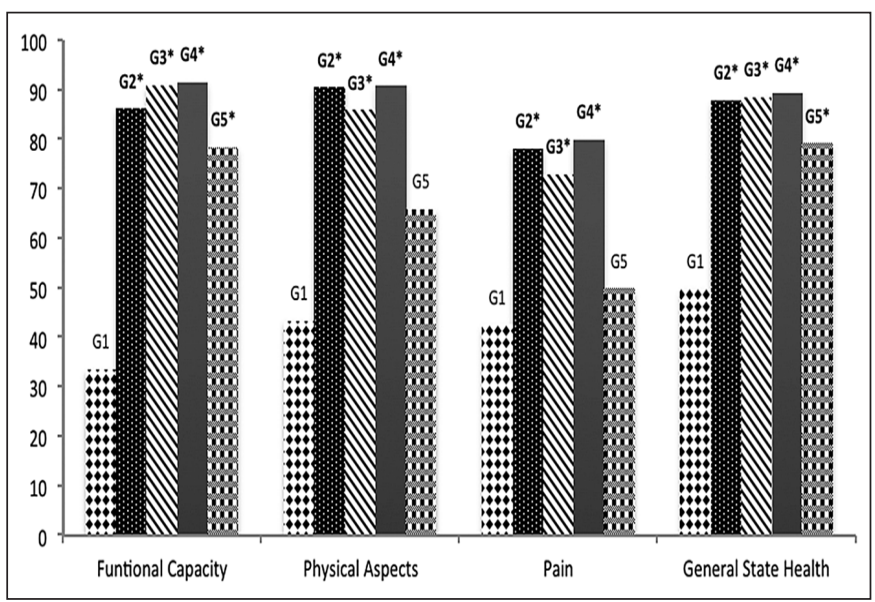

FIGURE 1A. Postoperative SF-36 questionnaire score for functional capacity, physical aspects, pain and general state of health. Data represented as mean. * Statistically significant compared to G1 $(P<0,05)$.

TABLE 3. Change in obesity related comorbidity after Roux-en-Y gastric bypass

\begin{tabular}{|c|c|c|c|c|c|}
\hline Comorbidity & $\mathrm{n}$ & Aggravated (\%) & Same $(\%)$ & Improved (\%) & Resolved (\%) \\
\hline Hypertension & 66 & $0(0)$ & $0(0)$ & $20(30.3)$ & $46(69.7)$ \\
\hline Diabetes mellitus & 34 & $0(0)$ & $1(2.9)$ & $3(8.8)$ & $30(88.2)$ \\
\hline Arthropathy & 40 & $0(0)$ & $0(0.0)$ & $29(72.5)$ & $11(27.5)$ \\
\hline Dyslipidaemia & 14 & $0(0)$ & $1(7.1)$ & $2(14.3)$ & $11(78.6)$ \\
\hline Cardiopathy & 2 & $0(0)$ & $0(0)$ & $2(100)$ & $0(0)$ \\
\hline Sleep apenoea & 21 & $0(0)$ & $0(0)$ & $10(47.6)$ & $11(52.4)$ \\
\hline Infertility & 1 & 0 & 0 & $1(0.0 \%)$ & $1(100.0 \%)$ \\
\hline
\end{tabular}

TABLE 4. Change in diabetes comorbidity after Roux-en-Y gastric bypass

\begin{tabular}{lccccc}
\hline Group & n & $\begin{array}{c}\text { Aggravated } \\
(\%)\end{array}$ & $\begin{array}{c}\text { Same } \\
(\%)\end{array}$ & $\begin{array}{c}\text { Improved } \\
(\%)\end{array}$ & $\begin{array}{c}\text { Resolved* } \\
(\%)\end{array}$ \\
\hline G 2 & 6 & $0(0)$ & $0(0)$ & $0(0)$ & $6(100)$ \\
G 3 & 12 & $0(0)$ & $0(0)$ & $0(0)$ & $12(100)$ \\
G 4 & 9 & $0(0)$ & $1(11.1)$ & $1(11.1)$ & $7(77.8)$ \\
G 5 & 7 & $0(0)$ & $0(0)$ & $2(28.6)$ & $5(71.4)$ \\
\hline
\end{tabular}

* $P=0,035$ (test for trend in proportions)
TABLE 5. Bariatric Analysis and Reporting Outcome System final outcomes per group

\begin{tabular}{lcccccc}
\hline Group & $\mathrm{n}$ & $\begin{array}{c}\text { Failure } \\
(\%)\end{array}$ & $\begin{array}{c}\text { Fair } \\
(\%)\end{array}$ & $\begin{array}{c}\text { Good } \\
(\%)\end{array}$ & $\begin{array}{c}\text { Very } \\
\operatorname{good}(\%)\end{array}$ & $\begin{array}{c}\text { Excellent } \\
(\%)\end{array}$ \\
\hline G 2 & 26 & $0(0)$ & $0(0)$ & $1(3.8)$ & $13(50.0)$ & $12(46.2)$ \\
G 3 & 30 & $0(0)$ & $1(3.3)$ & $3(10)$ & $13(43.3)$ & $13(43.3)$ \\
G 4 & 27 & $0(0)$ & $0(0)$ & $6(22.2)$ & $12(44.4)$ & $9(33.3)$ \\
G 5 & 30 & $0(0)$ & $0(0)$ & $7(23.3)$ & $14(46.7)$ & $9(30.0)$ \\
\hline
\end{tabular}




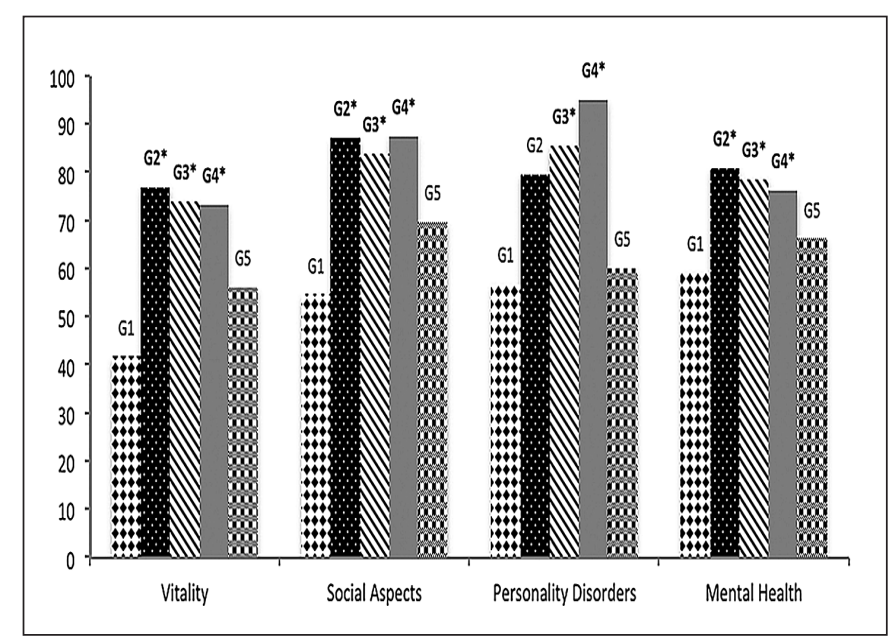

FIGURE 1B. Postoperative SF-36 questionnaire score for vitality, social aspects, personality disorders, mental health. Data represented as mean. * Statistically significant compared to G1 $(P<0,05)$.

\section{DISCUSSION}

Bariatric surgery has been the method most often used in obesity treatment for its effectiveness in weight loss, and for improvement of comorbidities and QoL. However it does not provide a definitive cure for obesity, and it requires persistence in behavioral and lifestyle changes after surgery ${ }^{(2,23)}$. In order to evaluate its outcomes, questionnaires have been used to collect data for comparison and for presentation effects. The lack of follow-up and the difficulty in obtaining completed questionnaires are factors that interfere with the interpretation of outcomes for postoperative bariatric patients $^{(5,10,12,24)}$. In fact, Puzziferri et al., that obtained $75 \%$ of RYGBP patient follow-up for 3 years, reported that an address or city change was a key factor causing loss of follow-up for these patients ${ }^{(20)}$. In an attempt to avoid the inconvenience and difficulty of long-term follow-up, we randomly selected patients who were treated in the Hospital of the Servidor Público Estadual de São Paulo covering different postoperative periods.

Weight loss is the main parameter of the success or failure of bariatric surgery, and it has been used in all systems for postoperative clinical outcome evaluations including BAROS, which is the most well-known questionnaire ${ }^{(17)}$. In the present study, the post-operative BMI ranged from $29.4 \pm 5.6$ to $31.6 \pm 4.3 \mathrm{Kg} / \mathrm{m}^{2}$ and the percentage of EBWL varied from $81.7 \pm 21.4 \%$ to $72.2 \pm 14.2 \%$, proportional to the postoperative period; however, no statistical differences were found among the postoperative groups. Similar findings were obtained by SEARS et al after 1 year of RYGBP in 75 patients with BMIs of $32.3 \pm 8.6$, and by Pajecki et al., who followed RYGBP patients for five to nine years and observed PEP $\% 2$ years after surgery of $80.2 \%$ (BMI 29.3 \pm 6.8 ) that decreased to $71.81 \%$ (BMI $35.5 \pm 10$ ) 5 years after surgery ${ }^{(18,22)}$.

Our findings showed a decrease in the proportion of a tendency for diabetes resolution over the long term. We think that partial weight return was seen in some individuals, although not enough to change the anthropometric data mean of the groups; this weight gain could have precipitated the return of insulin resistance and the necessity for hypoglycemic drugs. However, this could also be explained by the natural progression of the disease. In fact, Pajecki et al. noted that diabetes resolution occurred in $76.5 \%$ of the patients who underwent surgery, and the cases in which only clinical improvement occurred were associated with weight gain ${ }^{(18,22,27)}$.

The results obtained through BAROS demonstrated no differences between weight and comorbidities among groups, but after 1 and 2 years of follow-up, the QoL results, as measured by the Moorehead-Ardelt questionnaire, showed a decrease in this area among Groups 2 and 3 . However, this worsening result could be a bias of the study, because it did not occur after three and 4 years or more. In fact, the main factors associated with a worsening of QoL are insufficient loss of weight and depression ${ }^{(21)}$. Hence, factors besides weight that are not being investigated, such as psychological problems or not getting enough physical activity, could interfere with QoL questionnaire results.

The qualitative results from the BAROS showed that evaluation indices of very good or excellent results were greater than $90 \%$ in all groups. When we increased the number of the favorable results, it was observed that the rate of patients achieving good, very good, or excellent results was above $96 \%$. Such findings are similar to those of Puzziferri et al. who obtained $86 \%$ of good, very good, or excellent results 3 years after RYGBP, and Prevedello et al. who found very good and excellent results in more than $70 \%$ of the patients, and no results that were either moderate or insufficient ${ }^{(19,20)}$. This demonstrates that a high degree of patient satisfaction is always a positive finding.

Evaluation through use of the SF- $36^{\mathrm{TM}}$ questionnaire demonstrated results of significant improvement across all domains at the first year, which coincided with sudden changes in the weight loss experience. As years went on, however, as demonstrated by Group 5, these changes persisted in the study only for the domains of functional capacity and general state of health. This result perhaps occurred because, as a result of their weight loss, patients became physically capable of working and engaging in other social activities. However, other aspects, mostly emotional ones, such as anxiety, depression, or pessimism, affected physical and mental activities by a worsening of the QoL results. In the same manner, Kinzl et al. observed a worsening of QoL after weight gain, mostly among women who had psychiatric or personality disorders. Laurino Neto et al. did not observed changes in SF-36 domains related to physical functioning between preoperative and 3 years after RYGBP, and found a decrease in these parameters 7 years after surgery compared with preoperative perceptions ${ }^{(11)}$. On the other hand, Velcu et al. used the SF-36 questionnaire to evaluate patients who underwent RYGBP 5 years postsurgery, and they found no differences in the QoL in comparison to American populations who were not obese ${ }^{(25)}$. 
Moreover, other negative experiences can influence QoL, such as identity crises, persistent vomiting, restrictions on the ingestion of meat, and accumulation of excess skin ${ }^{(1,9)}$.

It is well known that the changes observed in the first few years after bariatric surgery related to weight loss encourage a patient's expectations of improving his or her self-esteem and facilitate his or her capacity for work and social relationships. The good evaluation results obtained during the initial years are justified by the effectiveness of weight loss, the favorable impact on comorbidities, and improvements in QoL. These results should be viewed by these patients as the stimulus required to change their lifestyle habits. The initial incentives prompted by the weight loss should be used in a correct manner with emphasis on physical activities, healthy nutrition, and psychological assessment to ensure long-term persistence of the favorable results obtained.

Costa RCNC, Yamaguchi N, Santo MA, Riccioppo D, Pinto Jr PE. Efeitos da gastroplastia em Y de Roux na qualidade de vida, perda de peso e controle de comorbidades. Arq Gastroenterol. 2014,51(3):165-70.

RESUMO - Contexto - A cirurgia bariátrica tem se sedimentado como o método mais eficaz de tratamento da obesidade mórbida. A avaliação da melhora de comorbidades e efeitos na qualidade de vida e, a manutenção destas alterações a longo prazo, são fatores com importantes influências no resultado do tratamento cirúrgico. Métodos - Estudo transversal foi realizado em 143 pacientes obesos da nossa instituição, entre fevereiro de 2007 a fevereiro de 2008. Estes pacientes foram divididos em cinco grupos independentes, sendo um deles o grupo de controle, além de outros quatro grupos com 1, 2, 3, e 4 ou mais anos de seguimento cirúrgico após gastroplastia em Y de Roux com uso de bandagem com anel de silicone. Avaliação da qualidade de vida e medidas antropométricas foram realizadas, e seus escores correlacionados com fatores sociais, perda de peso, e status de condições relacionadas com a obesidade. Resultados - Para o grupo de 1 ano de pós- operatório, uma porcentagem significativa de perda de excesso de peso corporal, $81,7 \%$, foi observada. Os grupos com 2, 3, e 4 ou mais anos de pós-operatório em acompanhamento mostraram um declínio da perda de excesso de peso, mas sem diferenças significativas. Os efeitos sobre as principais comorbidades em todos os pacientes operados foi de melhora, nos seguintes percentuais: $69,7 \%$ para a hipertensão arterial, $88,2 \%$ para o diabetes mellitus, e $27,5 \%$ artropatias. Houve uma diminuição significativa na taxa de resolução do diabetes $(P=0,035)$ ao longo do tempo de seguimento. Os resultados obtidos pelo escore BAROS foram bom, muito bom ou excelente em mais de $96 \%$ dos pacientes em todas as avaliações, demonstrando melhora na qualidade de vida. Além disso, a qualidade de vida também foi avaliada através do questionário SF- 36, e apresentou melhora em todas as áreas relacionadas após 1 ano da operação. No entanto, depois de 4 anos da cirurgia, a melhora permaneceu evidente apenas nas áreas de estado geral de saúde e capacidade funcional. Conclusão - A gastroplastia em Y de Roux com anel de silicone foi capaz de alcançar perda de excesso de peso de 81,7\% 1 ano após a cirurgia, permanecendo estável, com queda não significativa após este período no grupo estudado. Também evidenciou-se importantes efeitos no controle e resolução de comorbidades, como hipertensão arterial e diabetes. Resultados cirúrgicos imediatos avaliados pelo SF-36 na área de qualidade de vida foram satisfatórios, mas apenas o estado geral de saúde e a capacidade funcional mantiveram resultados positivos a longo prazo.

DESCRITORES - Cirurgia bariátrica. Derivação gástrica. Avaliação de resultados. Qualidade de vida. 


\section{REFERENCES}

1. Arasaki CH, Del Grande JC, Yanagita ET, Alvez AK, Oliveira DR. Incidence of regurgitation after the banded gastric bypass. Obes Surg. 2005;15:1408-17.

2. Buchwald H, Avidor Y, Braunwald E et al. Bariatric surgery: A systematic review and meta-analysis. JAMA. 2004;292:1724-37.

3. Canadian Community Health Survey (CCHS). Statistics Canada. [Internet]. [cited 2014 Feb 5]. Available from: http://www.statcan.gc.ca/start-debut-eng.html

4. Ciconelli RM, Ferraz MB, Santos W, Meinão I, Quaresma MR. Validation of SF-36 quality of life questionnaire translated into portuguese (Brazil SF-36). Rev Bras Reumatol. 1999;39:143-50.

5. Duval K, Marceau P, Perusse L, Lacasse Y. An overview of obesity-specific quality of life questionnaires. Obesity Reviews. 2006;7:347-60.

6. Flegal KM, Carroll MD, Ogden CL, Jonhson CL. Prevalence and trends in obesity among US adults, 1999-2000. JAMA. 2010;303:235-41.

7. Garrido Jr AB, Oliveira MR, Berti LV et al. Gastrointestinal bypass. In: Garrido Jr, editor. Obesity surgery. 1st ed. São Paulo: Atheneu; 2002. p. 155-61.

8. IBGE Brazilian Institute of Geography and Statistics: Survey of family budgets 2002-2003. [cited 2014 Feb 5]. [Internet]. Available from: http://www.ibge.gov.br/ home/estatistica/populacao/condicaodevida/pof/2002/.

9. Kinzl JF, Schrattenecker M, Traweger C, Aigner F, Fiala M, Biebl W. Quality of life in morbidly obese patients after surgical weight loss. Obes Surg. 2007;17:229-35.

10. Kolotkin RL, Meter K, Willians GR. Quality of life and obesity. Obesity reviews. 2001;2:219-29.

11. Laurino Neto RM, Herbella FAM. Changes in quality of life after short and long term follow-up of Roux-en-Y gastric bypass for morbid obesity. Arq Gastroenterol. 2013;3:186-90.

12. Levy RL, Finch EA, Crowell MD et al. Behavioral intervention for the treatment of obesity: strategies and effectiveness data. Am J Gastroenterol. 2007;102:2314-21.

13. Mokdad AH, Marks JS, Stroup D, Gerberding JL. Actual causes of death in the United States. JAMA. 2005;293:293-4.

14. National Institutes of Health. Clinical guidelines on the identification, evaluation and treatment of overweight and obesity in adults - The evidence report. Obes Res. 1998;6:51S-209S.
15. National Task Force on the Prevention and Treatment of Obesity. Overweight, obesity and health risk. Arch Intern Med. 2000;160:898-04.

16. NIH Conference. Gastrointestinal surgery for severe obesity. Consensus Development Conference Panel. Ann Intern Med. 1991;115:856-1.

17. Oria HE, Moorehead MK. Bariatric Analysis and Reporting Outcome System (BAROS). Obes Surg. 1998;8:487-99.

18. Pajecki D, Dalcanalle L, Oliveira CPMS, Zilberstein B, Halpern A, Garrido J AB, et al. Follow-up of Roux-en-Y Gastric Bypass Patients at 5 or more Years Postoperatively. Obes Surg, 2007;17:601-7.

19. Prevedello CF, Colpo E, Mayer ET, Copetti H. Analisis of the impact of bariatric surgery in a population of Rio Grande do Sul State using the BAROS method. Arq Gastroenterol. 2009;46:199-03.

20. Puzziferri N, Nguyen NT, Wolfe BM et al. Three-year follow-up of a prospective trial comparing laparoscopic versus open gastric bypass. Annals of Surgery. 2006;243:181-8.

21. Sanchez SR, Del Barrio MJ, Gonzalez C, Madico C, Terrado I, Gordillo ML et al. Long-term health-related quality of life following gastric bypass: influence of depression. Obes Surg. 2006;16:580-5.

22. Sears D, Fillmore G, Bui M, Rodriguez J. Evaluation of gastric bypass patients 1 year after surgery: changes in quality of life and obesity-related conditions. Obes Surg. 2008;18:1522-25.

23. Sjöström L, Lindroos AK, Peltonen M, Torgerson J, Bouchard C, Carlsson B et al. Swedish Obese Subjects Study Scientific Group. N Engl J Med. 2004;23:2683-3.

24. Valezi AC, Mali Jr J, Menezes MA, Brito EM, Souza JCL. Weight loss eight years after gastric bypass. Rev Col Bras Cir. 2011;38:232-6.

25. Velcu LM, Adolphine R, Mourelo R, Cottam DR, AnguS LD. Weight loss, quality of life and employment status after Roux-en-Y gastric bypass: 5-year analysis. Surg Obes Relat Dis. 2005;1:413-6.

26. Ware JE, Sherbourne CD. The MOS 36 Item Short-Form Health Survey (SF-36) I. Conceptual framework and item selection. Med Care. 1992;30:473-83.

27. Zeve JLM, Tomaz CAB, Nassif PAN, Lima JA, Sansana LRZ, Zeve CH. Obese patients with diabetes mellitus type 2 undergiong gastric bypass in Roux-en-Y: analysis of results and its influence in complications. Arq Bras Cir Dig. 2013; 26:47-52. 